\title{
MEDIA DAN KETAHANAN KELUARGA MUSLIM DI INDONESIA
}

\author{
Winda Kustiawan, Kartini \\ Fakultas Dakwah dan Komunikasi \\ Universitas Islam Negeri Sumatera Utara \\ Email: windakustiawan@gmail.com
}

\begin{abstract}
Abstrak
Seiring berkembangnya jaman dan banyaknya teknologi yang semakin berkembang. Hal tersebut disambut sebagai sebuah pembaharuan. Namun dalam pembaharuan belum tentu pondasinya mampu menahan pembaharuan itu tadi. Seperti contohnya tindak penipuan, pelecehan seksual, berita bohong, perselingkuhan, dan sebagainya, perilaku-perilaku tersebut seperti menerima fasilitas-fasilitas baru yang semakin memudahkan untuk melakukan perbuatan tersebut. Keluarga merupakan benteng yang harus menjaga keluarga dalam penggunaan media dalam kehidupan.
\end{abstract}

Kata Kunci: Media dan Ketahan Keluarga Muslim

\section{PENDAHULUAN}

Seluruh manusia hidup di dunia ini tentu mendambakan keamanan, kedamaian dan ketentraman dalam mewujudkannya itu. Untuk mewujudkan rasa aman ini manusia lebih membutuhkannya daripada kebutuhan akan makan dan lainnya. Karena itu Islam memperhatikan hal ini dengan cara membina manusia sebagai bagian dari masyarakat di atas akidah yang lurus disertai akhlak yang mulia. Bersamaan dengan itu, pembinaan individu-individu tidak mungkin dapat terlaksana dengan baik tanpa ada wadah dan lingkungan yang baik. Dari sudut inilah kita dapat melihat nilai sebuah keluarga itu harus dibentuk, diciptakan dan dibina.

Keluarga dalam Islam merupakan rumah tangga yang dibangun dari suatu pernikahan antara seorang pria dan wanita yang dilaksanakan sesuai syariat agama Islam yang memenuhi syarat pernikahan dan rukun nikah yang ada.

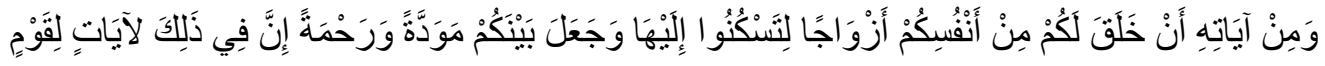

$$
\begin{aligned}
& \text { بَتَفَكَكُرُونَ }
\end{aligned}
$$

Artinya: Dan di antara tanda-tanda kekuasaanNya, ialah Dia menciptakan untukmu istri-istri dari jenismu sendiri, supaya kamu cenderung dan merasa tenteram kepadanya, dan dijadikanNya di antaramu rasa kasih dan sayang. 
Sesungguhnya pada yang demikian itu, benar-benar terdapat tanda-tanda bagi kaum yang berpikir." (Qs.Ar-Ruum : 21)

Keluarga dalam pandangan Islam memiliki nilai yang sangat besar sekali. Bahkan dalam Islam menaruh perhatian sangat besar terhadap kehidupan keluarga dengan meletakkan kaidah-kaidah yang arif guna memelihara kehidupan keluarga dari ketidakharmonisan dan kehancuran. Kenapa demikian besar perhatian Islam dengan keluarga. Tentunya tidak dapat dipungkiri bahwa keluarga adalah landasan utama untuk membangun istana masyarakat muslim dan merupakan madrasah iman yang diharapkan dapat mencetak generasi-generasi muslim yang mampu meninggikan agama Allah di muka bumi. Jika pondasi agama keluarga itu kuat, lurus agama dan akhlak anggotanya, maka akan kuat pula masyarakatnya dan terwujud pula keamanan yang didambakan. Namun sebaliknya apabila ikatan keluarga tercerai-berai dan kerusakan meracuni anggota-anggotanya maka dampak buruknya akan terlihat pada masyarakat. Bagaimana kegoncangan melanda dan rapuhnya kekuatan, sehingga tidak diperoleh rasa aman dalam kehidupan berbangsa dan bernegara serta bermasyarakat.

Ketidakharmonisan dan kehancuran dalam rumah tangga atau keluarga dapat terjadi karena faktor internal dalam keluaga. Biasanya pemicunya itu karena kelemahan ekonomi, perselingkuhan dan anak. Namun ada hal yang mengejutkan yang disampaikan oleh lembaga Pusat Unggulan Iptek Komputasi Berkinerja Tinggi Pusat Penelitian Informatika, Lembaga Ilmu Pengetahuan Indonesia (LIPI) pada akhir tahun 2017, mengemukan bahwa pengaruh smart phone, gadgat dan android dapat menimbulkan ketidakharmonisan dalam rumah tangga atau keluarga meingkat sampai $75 \%$ sampai dengan $85 \%$ pertahunnya. Ini adalah permasalahan yang sangat serius tentang ketahanan keluarga. ${ }^{1}$ Teknologi komunikasi telah berkembang sedemikian pesat, sehingga mengubah perilaku manusia. Dampak positif sangat banyak didapatkan dari teknologi ini, namun tidak jarang menimbulkan persoalan sampai ketingkat yang sangat berat yaitu di

1 Puspitawati, H., Herawati, T., Hastuti, D., Sunarti, T., \& Sarma, M. (2015). Pengembangan model operasional pendataan ketahanan keluarga untuk kegiatan pembangunan di tingkat kabupaten. Laporan penelitian, Kementerian Pemberdayaan Perempuan dan Perlindungan Anak-RI dengan Pusat Kajian Gender dan Anak-IPB. Atau dapat di telusuri http://ejurnal.kependudukan.lipi.go.id/index.php/jki/article/view/283 
dalam keluarga. Maka hal ini harus di sikapi dengan baik dalam membangun keluarga muslim di Indonesia.

\section{Media dan Perkembangannya}

Media massa adalah salah satu alat yang digunakan dalam berkomunikasi setiap hari, dimana saja dan kapan saja antara satu orang, dua orang atau lebih dengan orang yang lain. Hampir dipastikan setiap orang di dunia akan selalu memerlukan media massa untuk mendapatkan informasi mengenai kejadian di sekitarnya. Dengan adanya media massa pula orang akan mudah mendapatkan informasi yang mereka butuhkan setiap hari dan pada saat tertentu mereka menginginkan informasi. Untuk hal lainnya manusia dapat berbagi kejadiankejadian yang terjadi baik yang dirasakan maupun yang terjadi di sekitarnya kepada orang lain. Sehingga antara satu orang dengan orang lain dimanapun dan di daerah yang berbeda dapat melakukan pertukaran informasi mengenai kejadian disekitar mereka melalui media massa.

Media massa modern terbagi menjadi dua yaitu media massa yang tercetak dalam sebuah kertas (media cetak) dan media yang terdiri dari perangkat mesinmesin (media elektronik), media massa cetak misalnya majalah, surat kabar, dan lain sebagainya. Serta media elektronik seperti radio dan televisi, biasanya di sebut dengan media mainstream. Namun dengan perkembangan teknologi dan informasi mengalami perubahan dan peningkatan, sehingga muncul dengan nama media sosial. Media sosial sendiri adalah media online yang mendukung interaksi sosial. Sosial media menggunakan teknologi berbasis web yang mengubah komunikasi menjadi dialog interaktif. Beberapa situs media sosial yang populer sekarang ini antara lain: Blog, Twitter, Facebook, Instagram, Path, dan Wikipedia. ${ }^{2}$ Definisi lain dari sosial media juga di jelaskan oleh Van Dijk media sosial adalah platform media yang memfokuskan pada eksistensi pengguna yang memfasilitasi mereka dalam beraktivitas maupun berkolaborasi. Karena itu, media

2 Gusti Ngurah Aditya Lesmana, Tesis: Analisis Pengaruh Media Sosial Twitter Terhadap Pembentukan Brand Attachment (Studi: PT. XL AXIATA), (Program Magister Manajemen, Fakultas Ekonomi, Universitas Indonesia). h, 10-11 
sosial dapat dilihat sebagai fasilitator online yang menguatkan hubungan antar pengguna sekaligus sebagai sebuah ikatan sosial. ${ }^{3}$

Menurut Shirky media sosial dan perangkat lunak sosial merupakan alat untuk meningkatkan kemampuan pengguna untuk berbagi (to share), bekerja sama (to cooperate) diantara pengguna dan melakukan tindakan secara kolektif yang semuanya berada diluar kerangka institusional meupun organisasi. Media sosial adalah mengenai menjadi manusia biasa. Manusia biasa yang saling membagi ide, bekerjasama, dan berkolaborasi untuk menciptakan kreasi, berpikir, berdebat, menemukan orang yang bisa menjadi teman baik, menemukan pasangan, dan membangun sebuah komunitas. Intinya, menggunakan media sosial menjadikan kita sebagai diri sendiri. ${ }^{4}$

Beberapa pengertian diatas tentang penggunaan media sosial maka dapat disimpulkan penggunaan media sosial adalah proses atau kegiatan yang dilakukan seseorang dengan sebuah media yang dapat digunakan untuk berbagi informasi, berbagi ide, berkreasi, berfikir, berdebat, menemukan teman baru dengan sebuah aplikasi online yang dapat digunakan melalui smartphone (telefon genggam).

Merebaknya situs media sosial yang muncul menguntungkan banyak orang dari berbagai belahan dunia untuk berinteraksi dengan mudah dan dengan ongkos yang murah ketimbang memakai telepon. Dampak positif yang lain dari adanya situs jejaring sosial adalah percepatan penyebaran informasi. Akan tetapi ada pula dampak negatif dari media sosial, yakni berkurangnya interaksi interpersonal secara langsung atau tatap muka, munculnya kecanduan yang melebihi dosis, serta persoalan etika dan hukum karena kontennya yang melanggar moral, privasi serta peraturan. Dalam artikelnya berjudul "User of the World, Unite! The Challenges and Opportunities of Social Media," di Majalah Business Horizons (2010) Andreas M Kaplan dan Michael Haenlein membuat klasifikasi untuk berbagai jenis media sosial yang ada berdasarkan ciri-ciri penggunaannya.

\footnotetext{
${ }^{3}$ Michael Haenlein, Users of the world, unite! The challenges and opportunities of Social Media". (Business Horizons, 2010), h. 59-68

${ }^{4}$ Rulli Nasrullah, Media Sosial : Perspektif Komunikasi, Budaya, dan Sosioteknologi, (Bandung : Remaja Rosdakarya, 2017), h. 11
} 
Menurut mereka, pada dasarnya media sosial dapat dibagi menjadi enam jenis ${ }^{5}$, yaitu:

1. Proyek kolaborasi website, di mana user-nya diizinkan untuk dapat mengubah, menambah, atau pun membuang konten-konten yang termuat di website tersebut, seperti Wikipedia.

2. Blog dan microblog, di mana user mendapat kebebasan dalam mengungkapkan suatu hal di blog itu, seperti perasaan, pengalaman, pernyataan, sampai kritikan terhadap suatu hal, seperti Twitter.

3. Konten atau isi, di mana para user di website ini saling membagikan kontenkonten multimedia, seperti e-book, video, foto, gambar, dan lainlain seperti Instagram dan Youtube.

4. Situs jejaring sosial, di mana user memperoleh izin untuk terkoneksi dengan cara membuat informasi yang bersifat pribadi, kelompok atau sosial sehingga dapat terhubung atau diakses oleh orang lain, seperti misalnya facebook.

5. virtual game world, di mana pengguna melalui aplikasi 3D dapat muncul dalam wujud avatar-avatar sesuai keinginan dan kemudian berinteraksi dengan orang lain yang mengambil wujud avatar juga layaknya di dunia nyata, seperti online game.

6. Virtual social world, merupakan aplikasi berwujud dunia virtual yang memberi kesempatan pada penggunanya berada dan hidup di dunia virtual untuk berinteraksi dengan yang lain. Virtual social world ini tidak jauh berbeda dengan virtual game world, namun lebih bebas terkait dengan berbagai aspek kehidupan, seperti Second Life. ${ }^{6}$

${ }^{5}$ Tim Pusat Humas Kementerian Perdagangan RI, Panduan Optimalisasi Media Sosial Untuk Kemantrian Perdagangan RI, (Jakarta : Pusat Humas Kementerian Perdagangan RI, 2014), hal. 26

${ }^{6}$ Nuhu Mahnun, Media pembelajaran (kajian terhadap langkah-langkah pemilihan media dan implementasinya dalam pembelajaran), (An-Nida, Jurnal Pemikiran Islam, ISSN: 0853-1161, E-ISSN: 2407-1702, Vol. 37, No. 1, 2012), h. 72 
Muatan tentang media sosial diatas maka ciri-ciri media sosial adalah sebagai berikut: ${ }^{7}$

1. Konten yang disampaikan dibagikan kepada banyak orang dan tidak terbatas pada satu orang tertentu.

2. Isi pesan muncul tanpa melalui suatu gatekeeper dan tidak ada gerbang penghambat.

3. Isi disampaikan secara online dan langsung

4. Konten dapat diterima secara online dalam waktu lebih cepat dan bisa juga tertunda penerimaannya tergantung pada waktu interaksi yang ditentukan sendiri oleh pengguna.

5. Media sosial menjadikan penggunanya sebagai creator dan aktor yang memungkinkan dirinya untuk beraktualisasi diri.

6. Dalam konten media sosial terdapat sejumlah aspek fungsional seperti identitas, percakapan (interaksi), berbagi (sharing), kehadiran (eksis), hubungan (relasi), reputasi (status) dan kelompok (group). ${ }^{8}$

Mau tidak mau bahwa saat ini tidak dapat dipungkiri bahwa media sosial dalam perkembangan media telah mengambil peran dalam bentuk yang menandingi media-media konvensional atau tradisional, seperti televisi, radio, atau media cetak. Keunggulan itu dapat terjadi karena media sosial tidak membutuhkan tenaga kerja yang banyak, modal yang besar, dan tidak terikat oleh fasilitas infrastruktur produksi yang massif seperti kantor, gedung dan perangkat peliputan yang lain.

Media sosial merupakan bagian dari sistem relasi, koneksi dan komunikasi. Berikut ini sikap yang harus kita kembangkan terkait dengan peran, dan manfaat media sosial :

${ }^{7}$ Sumardi dan Endang, Perkembangan Media Sosial Era Millenial (Jakarta, Jurnal Media dan Komunikasi, ISSN. 23670, Tahun 2012), h. 83

${ }^{8} \mathrm{Ibid}$, h. 27 
1. Sebagai sarana belajar (To Education), mendengarkan, dan menyampaikan. Berbagai aplikasi media sosial dapat dimanfaatkan untuk belajar melalui beragam informasi, data dan isu yang termuat di dalamnya. Pada aspek lain, media sosial juga menjadi sarana untuk menyampaikan berbagai informasi kepada pihak lain. Konten-konten di dalam media sosial berasal dari berbagai belahan dunia dengan beragam latar belakang budaya, sosial, ekonomi, keyakinan, tradisi dan tendensi. Oleh karena itu, benar jika dalam arti positif, media sosial adalah sebuah ensiklopedi global yang tumbuh dengan cepat. Dalam konteks ini, pengguna media sosial perlu sekali membekali diri dengan kekritisan, pisau analisa yang tajam, perenungan yang mendalam, kebijaksanaan dalam penggunaan dan emosi yang terkontrol.

2. Sarana dokumentasi, administrasi dan integrasi. Bermacam aplikasi media sosial pada dasarnya merupakan gudang dan dokumentasi beragam konten, dari yang berupa profil, informasi, reportase kejadian, rekaman peristiwa, sampai pada hasil-hasil riset kajian. Dalam konteks ini, organisasi, lembaga dan perorangan dapat memanfaatkannya dengan cara membentuk kebijakan penggunaan media sosial dan pelatihannya bagi segenap karyawan, dalam rangka memaksimalkan fungsi media sosial sesuai dengan target-target yang telah dicanangkan. Beberapa hal yang bisa dilakukan dengan media sosial, antara lain membuat blog organisasi, mengintegrasikan berbagai lini di perusahaan, menyebarkan konten yang relevan sesuai target di masyarakat, atau memanfaatkan media sosial sesuai kepentingan, visi, misi, tujuan, efisiensi, dan efektifitas operasional organisasi.

3. Sarana perencanaan, strategi dan manajemen. Akan diarahkan dan dibawa ke mana media sosial, merupakan domain dari penggunanya. Oleh sebab itu, media sosial di tangan para pakar manajemen dan marketing dapat menjadi senjata yang dahsyat untuk melancarkan perencanaan dan strateginya. Misalnya saja untuk melakukan promosi, menggaet pelanggan 
setia, menghimpun loyalitas customer, menjajaki market, mendidik publik, sampai menghimpun respons masyarakat. ${ }^{9}$

Sarana kontrol, evaluasi dan pengukuran. Media sosial berfaedah untuk melakukan kontrol organisasi dan juga mengevaluasi berbagai perencanaan dan strategi yang telah dilakukan. Ingat, respons publik dan pasar menjadi alat ukur, kalibrasi dan parameter untuk evaluasi. Sejauh mana masyarakat memahami suatu isu atau persoalan, bagaimana prosedur-prosedur ditaati atau dilanggar publik, dan seperti apa keinginan dari masyarakat, akan bisa dilihat langsung melalui media sosial. Pergerakan keinginan, ekspektasi, tendensi, opsi dan posisi pemahaman publik akan dapat terekam dengan baik di dalam media sosial. Oleh sebab itu, media sosial juga dapat digunakan sebagai sarana preventif yang ampuh dalam memblok atau memengaruhi pemahaman publik. ${ }^{10}$

Selanjutnya McQuail berpendapat bahwa fungsi utama media bagi masyarakat adalah: ${ }^{11}$

a. Informasi-Inovasi, adaptasi, dan kemajuan.

b. Korelasi

- Menjelaskan, menafsirkan, mengomentari makna peristiwa dan informasi.

- Menunjang otoritas dan norma-norma yang mapan.

- Mengkoordinasi beberapa kegiatan.

- Membentuk kesepakatan.

c. Kesinambungan

- Mengekspresikan budaya dominan dan mengakui keberadaan kebudayaan. khusus (subculture) serta perkembangan budaya baru

\footnotetext{
${ }^{9}$ Haris Budiman, Peran Teknologi Informasi Dan Komunikasi Dalam Pendidikan, (AlTazkiyah, Jurnal Pendidikan Islam, ISSN: 2086-9118, E-ISSN: 2528-2476, Vol. 8, No. 1, 2017), h. 53

${ }^{10}$ Ibid, h. 34-37

${ }^{11}$ Denis McQuail, Teori Komunikasi Massa Suatu Pengantar, (Jakarta: Erlangga, 1992), hal. 71
} 
- Meningkatkan dan melestarikan nilai-nilai

d. Hiburan

- Menyediakan hiburan, pengalihan perhatian, dan sarana relaksasi

- Meredakan ketegangan sosial.

e. Mobilisasi

- Mengkampanyekan tujuan masyarakat dalam bidang politik, perang, pembangunan ekonomi, pekerjaan, dan kadang kala juga dalam bidang agama.

\section{Media Sosial Sebagai Penyebab Permasalahan Rumah Tangga}

Saat ini manusia dalam kehidupan modern yaitu agresif terhadap kemajuan. Majunya ilmu penegetahuan dan teknologi membuat manusia menemukan berbagai macam alat dan mesin yang mampu membantu manusia menyelesaikan apa-apa yang dikerjakannya menjadi lebih mudah cepat dan akurat. Pengaruh globalisasi terhadap keluarga ini tentunya ada yang berdampak positif dan negative. Dampak positif dapat berupa alat-alat yang dapat memudahkan pekerjaan manusia seperti computer, handphone, televise, dan alat mekanik rumah tangga lainnya. Sedangkan dampak negatifnya dapat berupa penyalah gunaan dari berbagai alat-alat tersebut, seperti pengaruh gaya hidup kebarat-baratan yang tidak sesuai dengan norma-norma yang berlaku. ${ }^{12}$

Semakin majunya tehnologi dari waktu ke masa sehingga tanpa disadari hidup di zaman C-Gen atau yang dikenal dengan connected generation, seperti yang ditulis Rhenald Kasali dalam bukunya "Cracking Zone" hidup pada generasi era digital. generasi yang sangat dekat dengan teknologi dan informasi. Semakin berkembang pesatnya tekologi dari waktu ke-waktu, menghasilkan banyak perubahan dalam kehidupan manusia, disaat yang sama teknologi diciptakan untuk mempermudah dan meningkatkan kualitas hidup

\footnotetext{
${ }^{12}$ Helmawati, Pendidikan Keluarga, (Bandung, PT. Remaja Rosdakarya : 2014), h. 248

13 Rhenald Kasali, Bagaimana Memetakan Perubahan di Abad 21 \& Keluar Dari Perangkap Comfort Zone "Cracking Zone" (Jakarta, Gramedia Pustaka Utama : 2013), h. 4 
Ironinya, tidak sedikit pula orang yang sulit mengadopsi teknologi baru, atau bahkan menolak adanya perubahan. ${ }^{14}$

Hidup di era conected generation yaitu dimana setiap orang bisa terhubung satu dengan yang lain hanya dengan sebuah komputer yaitu alat komunikasi mobil, membuat sangat dekatnya setiap orang dengan komunitasnya walau terpisah pulau, negara bahkan lautan sekalipun. Membuat hampir setiap orang pada dewasa ini terhubung dengan satu dengan lainnya untuk berkomuniaksi dengan salah satunya adalah situs jejaring sosial. Situs jejaring sosial, seakan sudah menjadi bagian dari kehidupan sehari-hari, bahkan pada sebagian orang merasakan ada sesuatu yang hilang apabila tidak terhubung dengan situs pertemanan alias situs jejaring sosial setiap hari. Sadarkah saat ini bahwa situs pertemanan jejaring sosial, dibalik manfaatnya yang memudahkan setiap orang untuk berkomunikasi, memiliki juga dampak negatif terhadap hubungan keluarga bahkan disinyalir menjadi salah satu penyebab perceraian di era globalisasi dan modern saat ini.

Jejaring Sosial merupakan suatu struktur sosial yang terbentuk dari simpul-simpul individu atau organisasi yang diikat dengan satu atau lebih tipe relasi spesifik seperti nilai, visi, ide, teman, keturunanan dan lain- lain. Hal ini dapat berhubung satu sama lainnya. Jejaring sosial juga dapat diartikan sebagai sebuah web berbasis pelayanan yang memungkinkan penggunanya membuat profil, melihat daftar pengguna lain yang tersedia dan dapat mengundang, dan menerima teman untuk ikut bergabung dalam situs jejaring sosial tersebut. Di dalamnya juga menampilkan halaman profil pengguna yang terdiri dari identitas diri dan foto pengguna. ${ }^{15}$

Situs jejaring sosial dapat memperlihatkan atau memamerkan foto-foto keluarga, teman, sahabat, keluarga bahkan foto-foto mesra. yang Ditengarai fotofoto mesra yang dipajang di dalam situs jejaring sosial dapat menjadi penyebab percekcokan pasangan suami istri ataupun pasangan. Uniknya, ternyata banyak

${ }^{14}$ Nurmansyah, Peran Keluarga, Masyarakat Dan Media Sebagai Sumber Informasi Kesehatan Reproduksi Pada Mahasiswa, (Jurnal Kesehatan Reproduksi, e-ISSN: 2354-8762, Vol. 3, No. 1 April 2012), h. 104

${ }^{15}$ Dirgayuza Setiawan, Facebook Untuk Pemula, (Jakarta, Media Jakarta : 2008), h. 6 
pasangan yang menemukan pasanganannya berselingkuh dari situs jejaring sosial sang pasangan. Untuk yang sudah berumah tangga harus lebih waspada dalam bersosial media, jangan sampai memasukkan laki-laki lain ke dalam rumah kita. Rumah yang dimaksud disini adalah kehidupan kita dari berbagai sisi. Jangan karena terbawa nostalgia misalnya ada seorang pria teman lama memulai perbincangan panjang via WhatsApp lalu kita dengan mudahnya melayani dia.

Padahal di dalam Islam, seorang istri wajib meminta ijin jika "rumah"nya dimasuki oleh pria lain, termasuk rumah dalam kehidupan dunia maya. Apabila media sosial semakin memperburuk keadaan dalam rumah tangga maka hal tersebut sudah tidak dibernarkan karena akan menimbulkan banyak konflik akibat kesalahfahaman.

Dampaknya anggota keluarga yang mengalami konflik atau permasalahan akan mengalami gangguan kejiwaan (psikologis), salah satunya akan tampak kecemasan dari ekspresi wajahnya. Dari kecemasan ini kemungkinan dapat berpengaruh pada sikap dan perilaku sehari-hari. Umumnya saat mengalami permasalahan anggota keluarga akan bereaksi melalui tiga cara. Pertama, ia akan menyesuaikan diri terhadap orang lain dalam rangka mencari perlindungan dan keamanan. Kedua, sebagai kompensasi dari rasa cemas dan takut, ia akan bersikap negatif dengan melihat orang lain sebagai musuh. Ketiga, ia akan menarik diri dari lingkungan, mengisolasi diri dan berusaha untuk mengatasi kecemasannya. ${ }^{16}$

\section{PEMBAHASAN}

\section{Ketahanan Keluarga Muslim dalam mengahadapi Era Digital}

Sosial media merupakan media yang dapat membuat kita mendapat siksa kubur/ nikmat kubur. Sosmed pulalah yang yang menjadi wasilah/media untuk memasukkan kita ke neraka atau ke surga, ia bagaikan pedang bermata dua. Barangsiapa tak pandai mengambil manfaatnya pastilah ia akan terbunuh karenanya. Maka dari itu, seorang muslim yang di zaman ini tidak pernah bisa lepas dengan sosmed harus mengetahui adab-adab dalam menggunakan sosmed, diantaranya :

\footnotetext{
${ }^{16}$ Helmawati, Pendidikan Keluarga ..., h. 146-147
} 
Pertama: Mengingat bahwa Islam menuntut kita membagi waktu dengan proporsional. Tidak ada yang melarang penggunaan sosmed, namun kita harus menjaga diri agar tidak terjerumus terlalu dalam ke dalam kelalaian memanfaatkan waktu. Dalam media sosial terdapat berbagai forum maupun grub yang dibentuk untuk mempermudah dalam bertukar informasi antar orang yang dikehendaki. Tidak mengapa kita mempunyai beberapa grup dalam suatu akun sosmed, asalkan kita pastikan ada manfaatnya. Namun jika grup-grup tersebut hanya berisi komen-komen tertawa, emoticon, dan jempol belaka, atau bahkan cenderung hal-hal haram lain, maka delete segera grup tersebut.

Kedua: Menanamkan dengan baik dalam hati bahwa setiap postingan, komen, copas, dan share kita di sosmed akan dihisab, semuanya dan tak ada yang terluput oleh Allah. sebagaimana firman Allah:

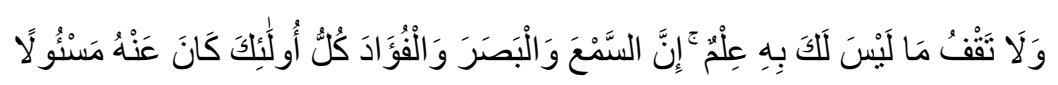

Artinya: Dan janganlah kamu mengikuti apa yang kamu tidak mempunyai pengetahuan tentangnya. Sesungguhnya pendengaran, penglihatan dan hati, semuanya itu akan diminta pertanggungan jawabnya (QS. Al-Isra : 36)

Karena Allah mempunyai malaikat yang ditugaskan untuk selalu mencatat setiap perbuatan kita. Kontrol diri kita agar tidak terlalu mudah memposting, berkomentar, copy-paste, dan menshare, dan diam adalah salah satu cara terampuh untuk mengontrolnya. Karena jari di dunia sosmed bagaikan lisan di dunia nyata. Semakin banyak teman yang kita yang menerima berbagai bentuk tulisan kita di sosmed, dan tulisan tersebut adalah tulisan yang salah, maka kelak semua teman kita akan menyalahkan kita ketika di akhirat

Ketiga: Ketika seseorang akan masuk dunia sosmed maka seseorang itu jangan lupa pasang niat. Niatkan semua karena Allah, niatkan untuk menjalin tali silaturahmi, niatkan untuk berbagi faedah yang disampaikan oleh para ustadz. ${ }^{17}$ Prinsipnya adalah menggunakan media sosial di era digital ini adalah tergantung cara pemanfaatannya dan penggunaanya. Apabila pemanfaatan dan penggunaannya adalah untuk perkara yang sia-sia dan tidak bermanfaat, maka

${ }^{17}$ Abdurrahman , Mandzumah Qawa'idh Fiqhiyyah, (Kebumen : Pustaka Sumayyah, 2010), h. 79 
media sosial bernilai sia-sia dan hanya membuang-buang waktu maka bisa haram dan berdosa. Karena efek tidak baik akan merusak sendi-sendi kehidupan keluarga. Namun apabila pemanfaatannya lebih besar dalam memenuhi kebutuhan hidup keluarga, maka media sosial menjadi sarana ibadah. ${ }^{18}$

\section{Pengaruh Gadget terhadap Perkembangan Anak}

Fenomena zaman sekarang anak-anak sudah mengenal teknologi nirkabel sejak kecil sehingga waktu dalam berinteraksi bersama keluarga sangat sedikit, karena lebih sering bersama smart phone atau gadgatnya. Hal ini disebabkan karena di usia 12-15 tahun, anak mengalami proses bangkitnya akal, nalar dan kesadaran diri. Masa ini terdapat energi atau memiliki kekuatan fisik serta tumbuh keinginan tahu dan keinginan coba-coba akan sesuatu yang baru dalam hidupnya. Sebuah data memperlihatkan bahwa ketika radiasi dari gadget memasuki kepala orang dewasa menyerapnya sebanyak 25\%, anak usia 12 tahun sebanyak 50\%, dan tertinggi pada anak usia 5 tahun, yaitu 75\%. Oleh karenanya, risiko kontraksi akan lebih besar pada anak yang sudah terbiasa dengan gadget atau smart phonenya di usia kurang dari 16 tahun. ${ }^{19}$

Pengaruh dalam penggunaan gadget atau smart phone terhadap perkembangan anak memiliki dampak positif dan dampak negatif. Dampak positif itu antara lain, membantu perkembanan fungsi adaptif seorang anak, menambah pengetahuan anak, memperluas jaringan persahabatan, mempermudah komunikasi, dan membangun kreatifitas anak. Sedangkan dampak negatifnya antara lain, anak menjadi ketergantungan terhadap gadget sehingga dalam menjalankan segala aktivitas hidupnya anak tidak bisa terlepas dari gadget, anak menjadi sulit berkonsentrasi pada dunia nyata, anak menjadi lebih suka bermain dengan gadgetnya daripada bermain dengan temannya, dan anak menjadi malas bergerak dan beraktivitas.

Dampak positif dalam penggunaan gadget atau smart phone antara lain: pertama adalah gadget akan membantu perkembangan fungsi adaptif seorang anak

\footnotetext{
${ }^{18}$ Ummu dan Abu Ihsan Al-Atsari, Aktualisasi Akhlaq Muslim, (Jakarta : Pustaka Imam Asy Syafi'I t.t, 2015), h. 154

${ }^{19}$ Jonathan,dkk., Perancangan Board Game Mengenai Bahaya Radiasi Gadget Terhadap Anak, ( Surabaya : Universitas Kristen Pertra Surabaya, 2015), h.115
} 
artinya kemampuan seseorang untuk bisa menyesuaikan diri dengan keadaan lingkungan sekitar dan perkembangan zaman. Jika perkembangan zaman sekarang muncul gadget, maka anakpun harus tahu cara menggunakannya karena salah satu fungsi adaptif manusia zaman sekarang adalah harus mampu mengikuti perkembangan teknologi. Sebaliknya, anak yang tidak bisa mengikuti perkembangan teknologi bisa dikatakan fungsi adaptifnya tidak berkembang secara normal. Nilai positif lain adalah gadget memberi kesempatan anak secara leluasa mencari informasi. Apalagi anak-anak sekolah sekarang dituntut untuk mengerjakan tugas melalui internet atau media sosial. ${ }^{20}$

Penggunaan gadget atau smart phone secara berlebihan pada anak akan berdampak negatif karena dapat menurunkan daya konsentrasi dan meningkatkan ketergantungan anak untuk dapat mengerjakan berbagai hal yang semestinya dapat mereka lakukan sendiri. Dampak lainnya adalah semakin terbukanya akses internet dalam gadget yang menampilkan segala hal yang semestinya belum waktunya dilihat oleh anak-anak. Banyak anak yang mulai kecanduan gadget dan lupa bersosialisasi dengan lingkungan sekitarnya yang berdampak psikologis terutama krisis percaya diri, juga pada perkembangan fisik anak. Dampak negatif akibat gadget atau smart phone bagi perkembangan anak sebagai berikut:

1. Sulit konsentrasi pada dunia nyata: Rasa kecanduan atau adiksi pada gadget akan membuat anak mudah bosan, gelisah dan marah ketika dia dipisahkan dengan gadget kesukaannya. Ketika anak merasa nyaman bermain dengan gadget kesukaannya, dia akan lebih asik dan senang menyendiri memainkan gadget tersebut. Akibatnya, anak akan mengalami kesulitan beriteraksi dengan dunia nyata, berteman dan bermain dengan teman sebaya.

2. Terganggunya fungsi PFC(Pre Frontal Cortex): Kecanduan teknologi selanjutnya dapat mempengaruhi perkembangan otak anak. PFC atau Pre Frontal Cortex adalah bagian didalam otak yang mengotrol emosi, kontrol diri, tanggung jawab, pengambilan keputusan dan nilai-nilai moral lainnya. Anak yang kecanduan teknologi seperti games online,

${ }^{20}$ Mohammad Nazir, Metode Penelitian, (Jakarta : Penerbit Ghalia Indonesia,2003), h.15 
otaknya akan memproduksi hormon dopamine secara berlebihan yang mengakibatkan fungsi PFC terganggu.

3. Introvert: Ketergantungan terhadap gadget pada anak-anak membuat mereka menganggap bahwa gadget itu adalah segala-galanya bagi mereka. Mereka akan galau dan gelisah jika dipisahkan dengan gadget tersebut. Sebagian besar waktu mereka habis untuk bermain dengan gadget. Akibatnya, tidak hanya kurangnya kedekatan antara orang tua dan anak, anak juga cenderung menjadi introvert. Selain daripada keterangan diatas, berikut dibawah ini merupakan dampak buruk penggunaan gadget pada anak antara lain : Menjadi pribadi tertutup, kesehatan otak terganggu, kesehatan mata terganggu, Kesehatan tangan terganggu, gangguan tidur, Suka menyendiri, prilaku kekerasan, pudarnya kreatifitas, terpapar radiasi, ancaman cyberbullying. ${ }^{21}$

\section{PENUTUP}

\section{Media Gadget atau Smart Phone dalam Pandangan Islam.}

Islam sangat senang sekali dengan kehidupan yang teratur danbermanfaat, maka dari itu kita sebagai khalifatul fill ardi berkewajiban menciptakan dan menebar manfaat dengan sekitarnya. Begitupula gadget dan smart phone yang menjadi kebutuhan manusia zaman sekarang, banyak sekali fasilitas-fasilitas yang sangat menunjang kebutuhan manusia. Dari sini terbukti bahwa gadget dan smart phone menebar manfaat untuk sekitar. Tetapi tidak sampai disana saja, bahwa banyak sekali manusia yang tergelincir ke lingkaran maksiat dengan menggunakan gadget dan smart phone. Tidak jarang seseorang lupa waktu akibat terlalu termanjakan oleh yang bernamakan gadget dan smart phone. Salah satunya adalah apilkasi Social Media dan Game.

Dua hal ini terkadang selalu membuat kita tidak mau melepas begitu saja. Apakah fasilitas ini bermanfaat? Ataukah tidak sama sekali? Maka dari itu kita selaku pengguna harus paham terhadap apa yang kita gunakan dan

${ }^{21}$ Derry Iswidharmanjaya \& Beranda Agency, Bila Si Kecil Bermain Gadget, (Jakarta, Bisakimia : 2014), h.15 
menggunakannya secara bijak. Segala sesuatu yang sifatnya sia-sia atau mubadzir adalah sifat setan. Allah berfirman dalam alquran surah al-Isra ayat 27 sebagai berikut:

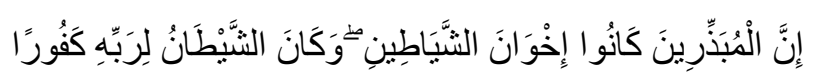

Artinya: "Sesungguhnya pemboros-pemboros itu adalah saudara-saudara syaitan dan syaitan itu adalah sangat ingkar kepada Tuhannya".

Keterangan surah al-Isra ayat 27 diatas menegaskan segala hal yang tidak bermanfaat atau terkesan berlebihan adalah bentuk dari makar setan agar dalam hidup manusia melakukan hal yang sia-sia. Karena kita tahu hidup di dunia ini sejatinya hanyalah untuk beribadah. Bermain gadget dan smart phone tidaklah diharamkan, namun harus ada porsi tersendiri karenannya orang yang sudah kecanduaan dengan gadget dan smart phone akan selalu merasa kurang dalam hidupnya jika belum bermain gadget dan smart phone dalam kesehariannya. Akan lebih parah lagi saat gadget dan smart phone menjadi Tuhan, karena gadget dan smart phone seseorang melupakan ibadah, seperti sholat karena begitu asyiknya, begitu bersemangatnya yang ujung-ujungnya ibadah wajibpun luput dari ingatan. Hal ini juga menjadi patologi sosial ketika seseorang tidak melakukan kegiatan apapun kecuali bermain gadget dan smart phone, akhirnya melupakan interaksi sosial, manusia diciptakan untuk saling mengenal satu-sama lain dan itu juga menjadi perintah agama, dalam surat $\mathrm{Al}$ hujurat ayat 13 berbunyi :

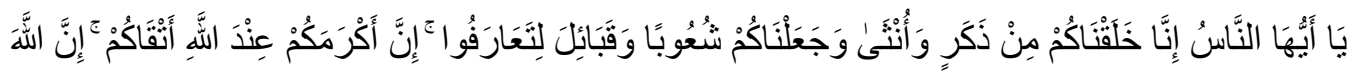

$$
\begin{aligned}
& \text { عَلِيمّ خَبِير }
\end{aligned}
$$

Artinya: "Hai manusia, sesungguhnya Kami menciptakan kamu dari seorang lakilaki dan seorang perempuan dan menjadikan kamu berbangsa-bangsa dan bersuku-suku supaya kamu saling kenal-mengenal. Sesungguhnya orang yang paling mulia diantara kamu disisi Allah ialah orang yang paling takwa diantara kamu. Sesungguhnya Allah Maha Mengetahui lagi Maha Mengenal". ${ }^{22}$

Sangat menyalahi perintah ketika seseorang tidak melakukan perintah Tuhan dalam bersosialisasi dengan sesama karena kodrat manusia adalah makhluk sosial yang membutuhkan satu sama lain.

${ }^{22}$ Enang Sudrajat, Departemen Agama RI Al-Qur'an dan Terjemahnya Special for Woman, (Bandung : Syamil Quran,2007), h.517 


\section{KESIMPULAN}

Media sosial masuk kedalam kehidupan manusia melalui perkembangan alat komunikasi seperti hand phone atau gadgat. Dalam penggunaannya seseorang dapat mengoperasikan media sosial dengan sangat leluasa. Bahkan untuk orang yang ingin menyalahgunakan fitur dari hand phone yang dimilikinya dirasa sangat mudah dan efisien karena hand phone atau gadgat sekarang sangat mendukung untuk digunakan dalam mengakses jejaring sosial.

Pengaruh-pengaruh yang timbul dalam penggunaan teknologi telekomunisi sangatlah berpengaruh dalam kehidupan manusia. Dalam segi positifnya yaitu mempermudah kerja dan kinerja manusia, memberikan kemudahan dalam berinteraksi dan berhubungan, perkembagan dari segi finansial (online shop, iklan, dan lainnya). Namun selain itu dari segi negatifnya hal- hal yang dapat timbul adalah menjadikan manusia semakin malas karena sangat bertumpu kepada teknologi, penyalahgunaan media sosial, serta penipuan melalui sosial media, dan lainnya.

\section{DAFTAR PUSTAKA}

Abdurrahman , Mandzumah Qawa'idh Fiqhiyyah, Kebumen : Pustaka Sumayyah, 2010.

Denis McQuail, Teori Komunikasi Massa Suatu Pengantar, Jakarta: Erlangga, 1992.

Dirgayuza Setiawan, Facebook Untuk Pemula, Jakarta, Media Jakarta : 2008

Derry Iswidharmanjaya \& Beranda Agency, Bila Si Kecil Bermain Gadget, Jakarta, Bisakimia : 2014.

Enang Sudrajat, Departemen Agama RI Al-Qur'an dan Terjemahnya Special for Woman, Bandung : Syamil Quran,2007.

Gusti Ngurah Aditya Lesmana, Tesis: Analisis Pengaruh Media Sosial Twitter Terhadap Pembentukan Brand Attachment, Studi: PT. XL AXIATA), Program Magister Manajemen, Fakultas Ekonomi, Universitas Indonesia.

Helmawati, Pendidikan Keluarga, Bandung, PT. Remaja Rosdakarya : 2014

Haris Budiman, Peran Teknologi Informasi Dan Komunikasi Dalam Pendidikan, Al-Tazkiyah, Jurnal Pendidikan Islam, ISSN: 2086-9118, E-ISSN: 25282476, Vol. 8, No. 1, 2017

Jonathan,dkk., Perancangan Board Game Mengenai Bahaya Radiasi Gadget Terhadap Anak, Surabaya : Universitas Kristen Pertra Surabaya, 2015.

Mohammad Nazir, Metode Penelitian, Jakarta : Penerbit Ghalia Indonesia, 2003 
Michael Haenlein, Users of the world, unite! The challenges and opportunities of Social Media". Business Horizons, 2010.

Nurmansyah, Peran Keluarga, Masyarakat Dan Media Sebagai Sumber Informasi Kesehatan Reproduksi Pada Mahasiswa, (Jurnal Kesehatan Reproduksi, eISSN: 2354-8762, Vol. 3, No. 1 April 2012.

Nuhu Mahnun, Media pembelajaran (kajian terhadap langkah-langkah pemilihan media dan implementasinya dalam pembelajaran), An-Nida, Jurnal Pemikiran Islam, ISSN: 0853-1161, E-ISSN: 2407-1702, Vol. 37, No. 1, 2012.

Puspitawati, H., Herawati, T., Hastuti, D., Sunarti, T., \& Sarma, M. (2015). Pengembangan model operasional pendataan ketahanan keluarga untuk kegiatan pembangunan di tingkat kabupaten. Laporan penelitian, Kementerian Pemberdayaan Perempuan dan Perlindungan Anak-RI dengan Pusat Kajian Gender dan Anak-IPB. Atau dapat di telusuri http://ejurnal.kependudukan.lipi.go.id/index.php/jki/article/view/283

Rhenald Kasali, Bagaimana Memetakan Perubahan di Abad 21 \& Keluar Dari Perangkap Comfort Zone "Cracking Zone", Jakarta, Gramedia Pustaka Utama : 2013.

Rulli Nasrullah, Media Sosial : Perspektif Komunikasi, Budaya, dan Sosioteknologi, (Bandung : Remaja Rosdakarya, 2017.

Sumardi dan Endang, Perkembangan Media Sosial Era Millenial, Jakarta, Jurnal Media dan Komunikasi, ISSN. 23670, Tahun 2012.

Tim Pusat Humas Kementerian Perdagangan RI, Panduan Optimalisasi Media Sosial Untuk Kemantrian Perdagangan RI, Jakarta : Pusat Humas Kementerian Perdagangan RI, 2014.

Ummu dan Abu Ihsan Al-Atsari, Aktualisasi Akhlaq Muslim, Jakarta : Pustaka Imam Asy Syafi'I t.t, 2015. 